(C)Carcinological Society of Japan. doi: 10.18353/crustacea.50.0_107

\title{
Catoptrus lavicolus, a new species of swimming crab (Crustacea, Brachyura, Portunidae) from shallow subtidal lava rock field at Sakurajima, an active volcano in Kagoshima, southern Japan
}

Tohru Naruse, Daisuke Uyeno

\begin{abstract}
A new species of swimming crab of the genus Catoptrus A. MilneEdwards, 1870 (Portunidae) is described from Kagoshima, southern Japan. Catoptrus lavicolus n. sp. was collected from deep inside large lava rocks at shallow subtidal bed of Sakurajima, an active volcano. The new species differs from all seven congeners by a combination of the characters of the carapace, chelipeds and ambulatory legs. Intersex specimens of C. lavicolus n. sp. were observed in this study, while no male specimen has been collected.
\end{abstract}

LSID urn:lsid:zoobank.org:pub:9E946E15-69A0-4F7B-B43A-2856632A5089

Key words: Taxonomy, Portunoidea, Kyushu, intersex

\section{Introduction}

The portunoid crab genus Catoptrus A. Milne-Edwards, 1870, currently contains seven species: C. nitidus A. Milne-Edwards, 1870 (type species; type locality, Samoa); C. inaequalis (Rathbun, 1906) (type locality, Molokai Island, Hawaiian Islands); C. rathbunae Serène, 1966 (type locality, Nhatrang, Vietnam); C. quinquedentatus Yang, Chen \& Tang, 2006 (type locality, Hainan Island, China); $C$. undulatipes Yang, Chen \& Tang, 2006 (type locality, Xisha Island, South China Sea); $C$. marigondonensis Takeda, 2010 (type locality, Marigondon Cave, Mactan Island, Philippines); and C. iejima Fujita \& Naruse, 2011 (type locality, Ie Island, Ryukyu Islands, Japan) (A. Milne-Edwards, 1870; Rathbun, 1906; Serène, 1966; Yang et al., 2006; Ng et al., 2008; Takeda, 2010; Fujita \& Naruse, 2011).

Recently one of us (DU) collected specimens assignable to an undescribed species of Catoptrus, which had an orange coloration and long, slender ambulatory legs from deep inside large lava rocks at a shallow subtidal bed of Sakurajima, an active volcano in Kagoshima, southern Japan (Fig. 1). The present study describes the new species in detail.

The measurements provided are carapace length measured at midline (CL) and maximum carapace width $(\mathrm{CW})$ respectively. The abbreviations used in this paper are as follows: en, endopod; ex, exopod; G1, G2, male first and second gonopods; P2-P5, second to fifth pereopods; pl, pleopod; L, left; R, right. Specimens examined are deposited in Kagoshima University Museum, Kagoshima (KAUM); Muséum national d'Histoire naturelle (MNHN), Paris; the Ryukyu University Museum, Fujukan (RUMF), Okinawa, Japan; US National Museum of Natural History, Smithsonian Institution, Washington DC (USNM); and the Zoological Reference Collection (ZRC), Raffles Museum of Biodiversity Research, National University of Singapore. 


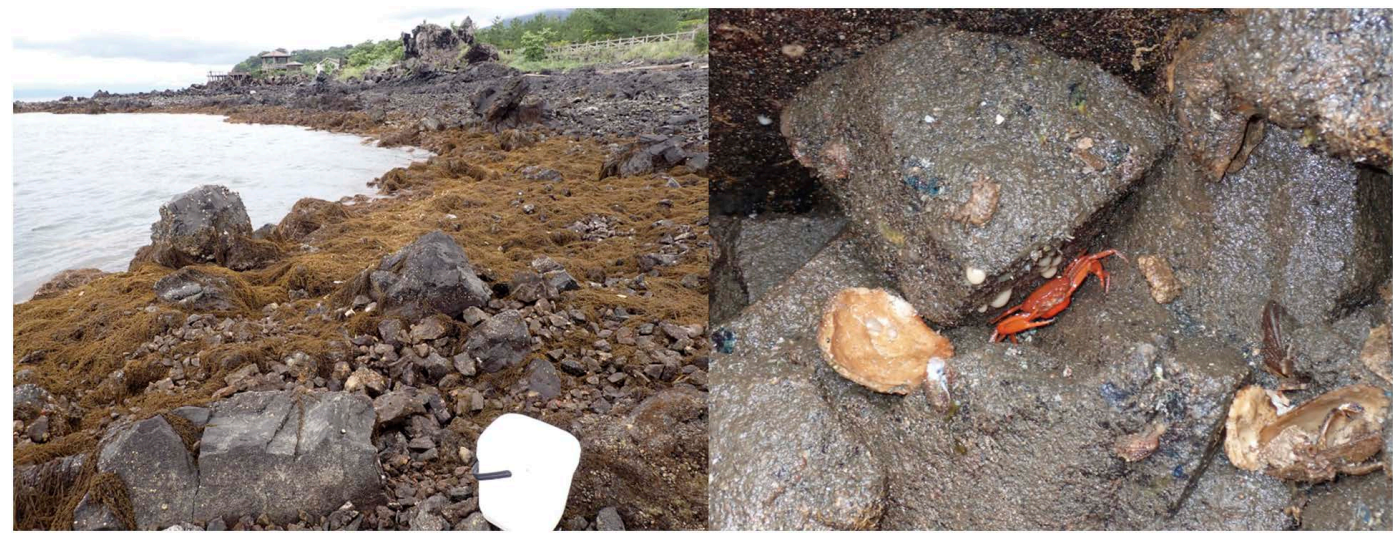

Fig. 1. Lava rock field and habitat of Catoptrus lavicolus $\mathbf{n}$. sp. The crab was found subtidally (see Ecological Notes).

\section{Taxonomy}

Family Portunidae Rafinesque, 1815

Subfamily Carupinae Paulson, 1875

Genus Catoptrus A. Milne-Edwards, 1870

Catoptrus lavicolus, n. sp.

[Japanese name: Yougan-hai-gazami]

(Figs. 1B, 2-7)

LSID urn:1sid:zoobank.org:act:FB429071-

2A8D-44ED-8FEC-E9A8E2121239

Material examined. All specimens were collected from Sakurajima Yogan Nagisa Park, Sakurajima, Kagoshima, Kyushu, Japan $\left(31^{\circ} 35^{\prime} \mathrm{N}, 130^{\circ} 35^{\prime} \mathrm{E}\right)$. See Ecological note for details on the habitat.

Holotype, RUMF-ZC-5988, female, $13.8 \times$ $22.4 \mathrm{~mm}$, coll. D. Uyeno \& K. Nagayoshi, 9 May 2020. Paratypes: RUMF-ZC-5989, 3 females, $9.5 \times 15.7-12.4 \times 20.4 \mathrm{~mm}, 1$ intersex, $7.9 \times 12.9 \mathrm{~mm}$, coll. D. Uyeno \& K. Nagayoshi, 9 May 2020; RUMF-ZC-5990, 2 females, $8.7 \times 14.5$, ca. $14.5 \times$ ca. $20.9 \mathrm{~mm}$ (damaged), 1 intersex, $6.2 \times 10.0 \mathrm{~mm}$, coll. D. Uyeno, 27 May 2021; RUMF-ZC-5991, 5 females, $4.7 \times$ $7.5-15.0 \times 24.6 \mathrm{~mm}, 1$ ovigerous female, 12.2 $\times 20.2 \mathrm{~mm}, \quad 2$ intersex, $6.4 \times 10.2, \quad 8.1 \times$ $13.6 \mathrm{~mm}$, coll. D. Uyeno, K. Nagayoshi \& K. Shinomiya, 28 May 2021; KAUM-AT-1421, 1 female, $13.2 \times 21.4 \mathrm{~mm}$, coll. D. Uyeno, K.
Nagayoshi \& K. Shinomiya, 28 May 2021; ZRC 2021.0702, 2 females, $10.4 \times 16.7,13.0$ $\times 21.2 \mathrm{~mm}$, coll. D. Uyeno, K. Nagayoshi \& K. Shinomiya, 28 May 2021.

Comparative material. Catoptrus iejima Fujita \& Naruse, 2011: holotype, female, RUMF-ZC-1317, 21.8 $\times 35.6 \mathrm{~mm}$, point "Ohoba No. 1", Ie Island, Ryukyu Islands, Japan, -10 m, submarine cave, baited with Pacific saury (Cololabis saira), coll. Y. Yamada \& K. Yunokawa, 15 Jul. 2010. Catoptrus inaequalis (Rathbun, 1906) (photographs): syntype, USNM 29657, 1 male, $6.9 \times 10.6 \mathrm{~mm}$, Auau Channel, 13-43 fathoms (23.8-78.6 m), US Fish Commission, Steamer Albatross, sta. 3871. Catoptrus nitidus A. Milne-Edwards, 1870 (photographs): MNHN B-4639, 1 male, 15.6× 23.9 mm, Iles Viti; MNHN B-22342, 2 males, $7.8 \times 12.1 \mathrm{~mm}, 6.5 \times$ ca. $10.1 \mathrm{~mm}$ (damaged), 1 juvenile $4.2 \times 6.4 \mathrm{~mm}$, Samoa. Catoptrus rathbunae Serène, 1966 (photographs): holotype, male, $5.0 \times 7.0 \mathrm{~mm}$, MNHN B-5564, Nhatrang, Vietnam, coll. R. Serène, 14 Aug. 1964; paratype, 1 female, $6.0 \times 8.5 \mathrm{~mm}$, MNHN B-5563, same data as holotype.

Diagnosis. Carapace ovoid, CW 1.59-1.68 times CL (mean 1.63, $\mathrm{n}=13$ ). Supraorbital margin minutely beaded, without fissure; infraorbital margin usually with 2 large 


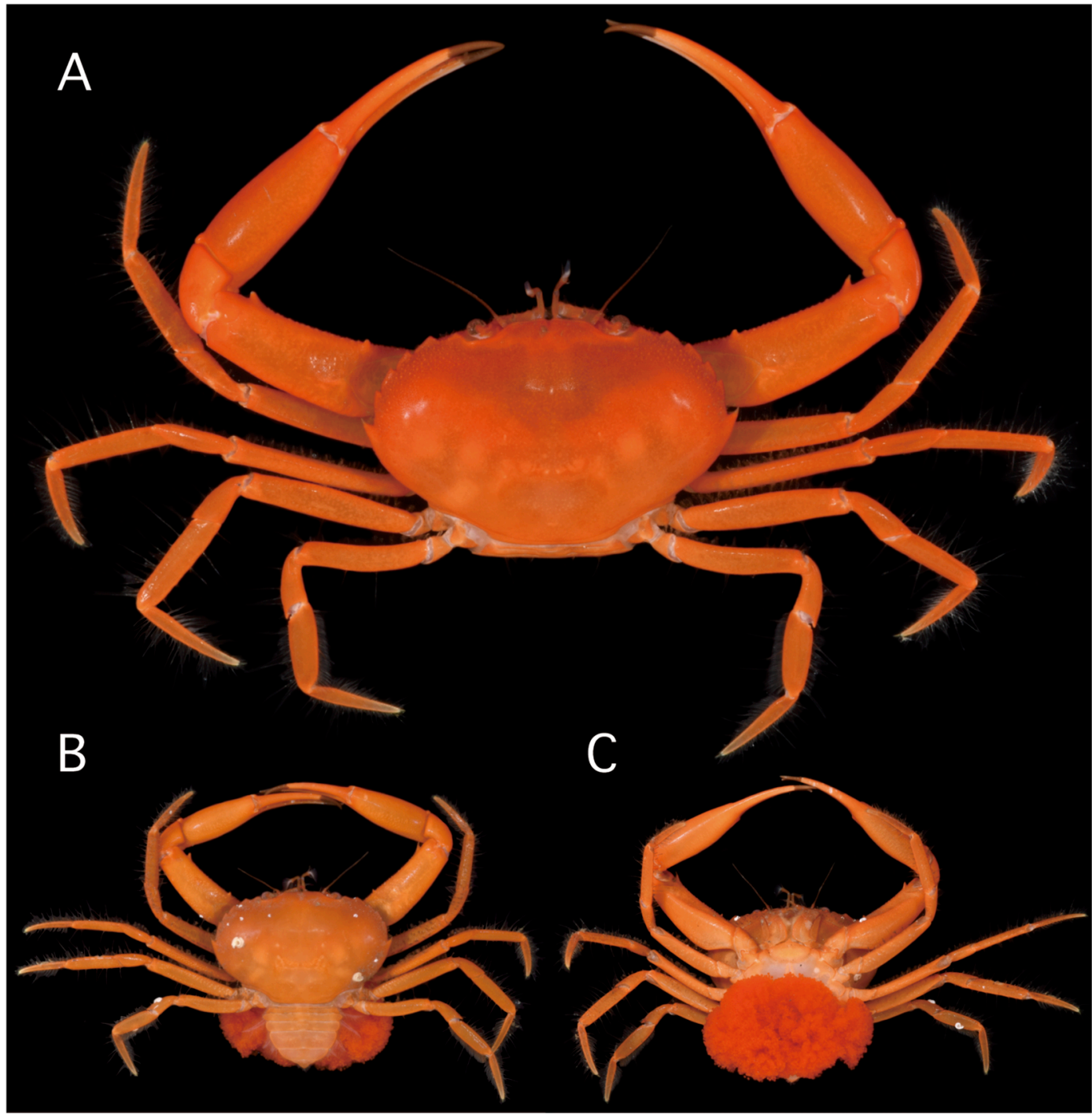

Fig. 2. Live coloration of Catoptrus lavicolus n. sp. A, KAUM-AT-1421, paratype, female, $13.2 \times 21.4$ mm; B, C, RUMFZC-5991, paratype, ovigerous female, $12.2 \times 20.2 \mathrm{~mm}$.

median teeth, mesial end forming triangular inner orbital tooth. External orbital angle triangular, only slightly exceeding or almost same level with tip of first anterolateral tooth, first anterolateral tooth slightly larger than external orbital angle. Anterolateral margins with 5 teeth excluding external orbital angle, tips of first to fourth teeth almost equidistant, fifth tooth sharp, longest, bases of these teeth adjacent to each other. Eyes relatively small, leaving small space between tip of eye and lateral end of orbit. Chelipeds slender; merus length to width ratio of holotype 2.83 (major), 3.24 (minor) (ca. 3.05-3.10 in a small individual), lower-anterior margin of merus with 1 subproximal, 1 subdistal small tooth each, respectively; palm slender, glabrous, without any striae or granules; fingers slender, slightly shorter than palm, tips claw-like and crossing when closed; immovable finger 


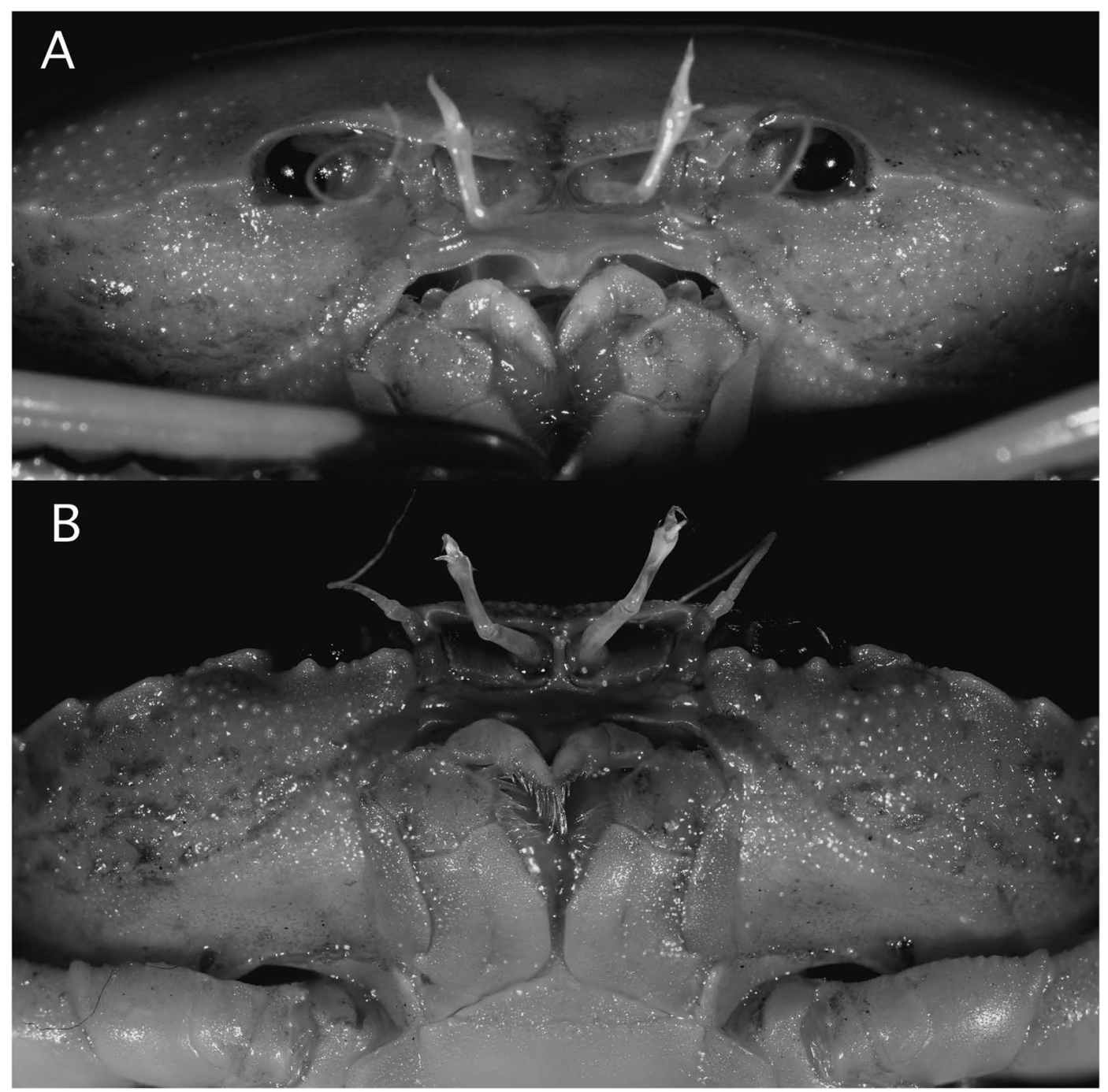

Fig. 3. Catoptrus lavicolus n. sp. Holotype, RUMF-ZC-5988, female, $13.8 \times 22.4 \mathrm{~mm}$. A, cephalothorax, anterior view; B, cephalothorax, anteroventral view.

occlusal margin with 4 large teeth, distal teeth sharper, with smaller teeth in between them; movable finger occlusal margin with 3 low, triangular teeth, which interdigitate with 4 large teeth on immovable finger occlusal margin. Ambulatory legs slender, long; ratios of lengths of P2-P5 meri to CL of holotype $0.82,0.88,0.75,0.57$, respectively; $\mathrm{P} 4$ merus length of holotype 4.92 times its width; propodus of P5 with weakly convex inner, outer margins; P5 dactylus lanceolate; P2-5 dactylus narrower than respective propodus.

Description. Carapace ovoid, CW 1.591.68 times CL (mean 1.63, $\mathrm{n}=13$ ), convex longitudinally, transversely, dorsal surface smooth, regions poorly defined (Figs. 2A, B, 3A, 4A). Front bilobed, with small median notch, frontal margin straight in dorsal view, weakly sloping downward medially in anterior view, minutely beaded; supraorbital margin minutely beaded, without fissure; infraorbital margin usually 


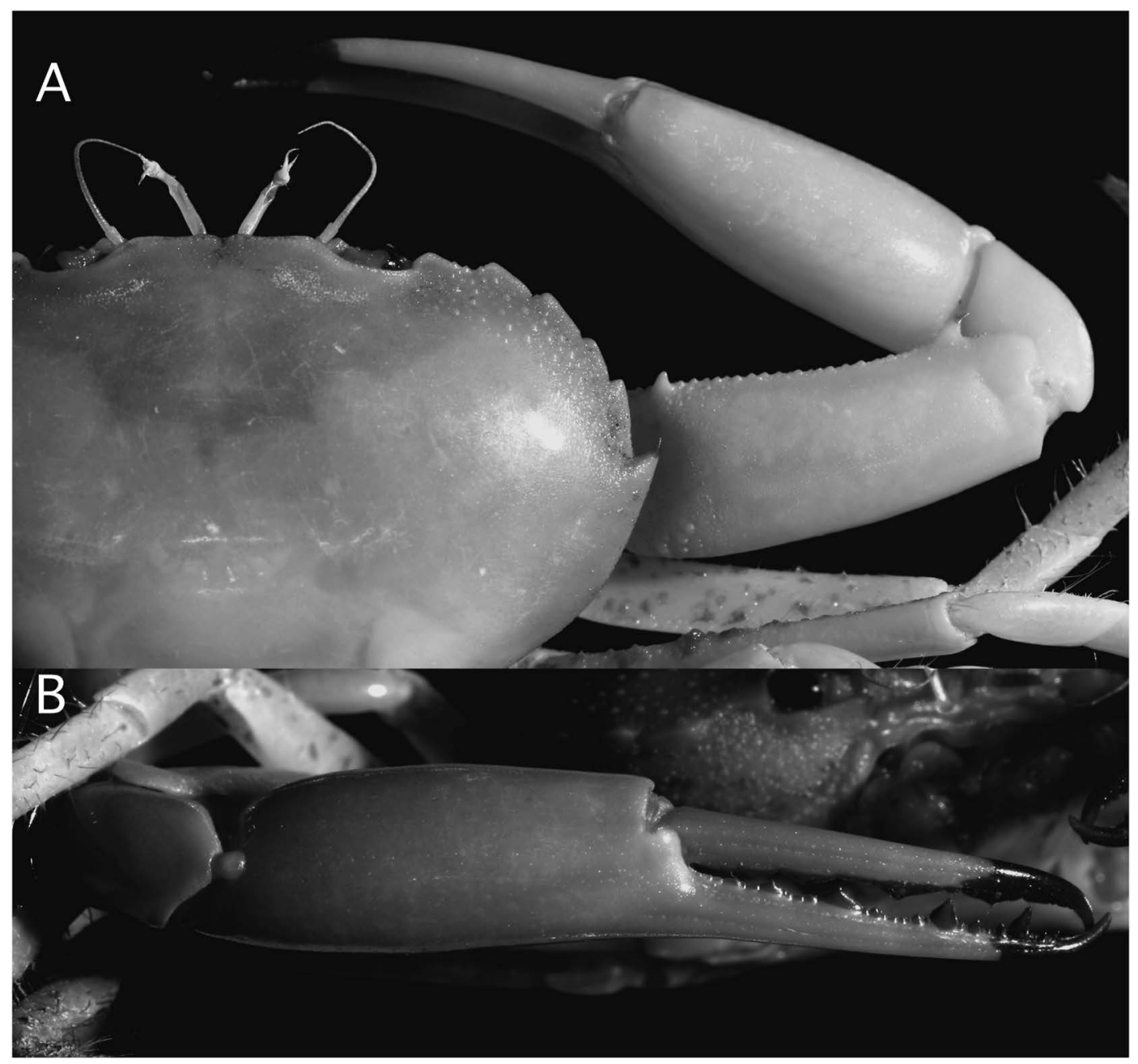

Fig. 4. Catoptrus lavicolus n. sp. Holotype, RUMF-ZC-5988, female, $13.8 \times 22.4 \mathrm{~mm}$. A, anterolateral region of cephalothorax and right cheliped, dorsal view; $\mathrm{B}$, right chela, outer view.

with 2 large median teeth, mesial end forming triangular inner orbital tooth (Figs. 2A, B, 3, 4A). External orbital angle triangular, only slightly exceeding or almost same level with tip of first anterolateral tooth, first anterolateral tooth slightly larger than external orbital angle (Figs. 1A, B, 4A). Antero- and posterolateral margins (Fig. 1A, B) almost of same length; anterolateral margin with 5 teeth excluding external orbital angle, tips of first to fourth teeth almost equidistant, fifth tooth sharp, longest, bases of these teeth adjacent to each other.

Epistome (Fig. 3A) with posterior margin medially produced, produced part medially notched, posterior margin rimmed, beaded, except for median notch.

Eyes relatively small, leaving small space between tip of eye and lateral end of orbit; eyestalk with L-shaped prominence along proximal margin of cornea of anterior surface to concave part of cornea on upper surface; cornea small, slightly narrower than base of peduncle (Figs. 3A). Antennular basal article large, antennular fossa large, high. Distomesial angle of basal antennal article touching ventral extension of distolateral angle of front (Fig. 


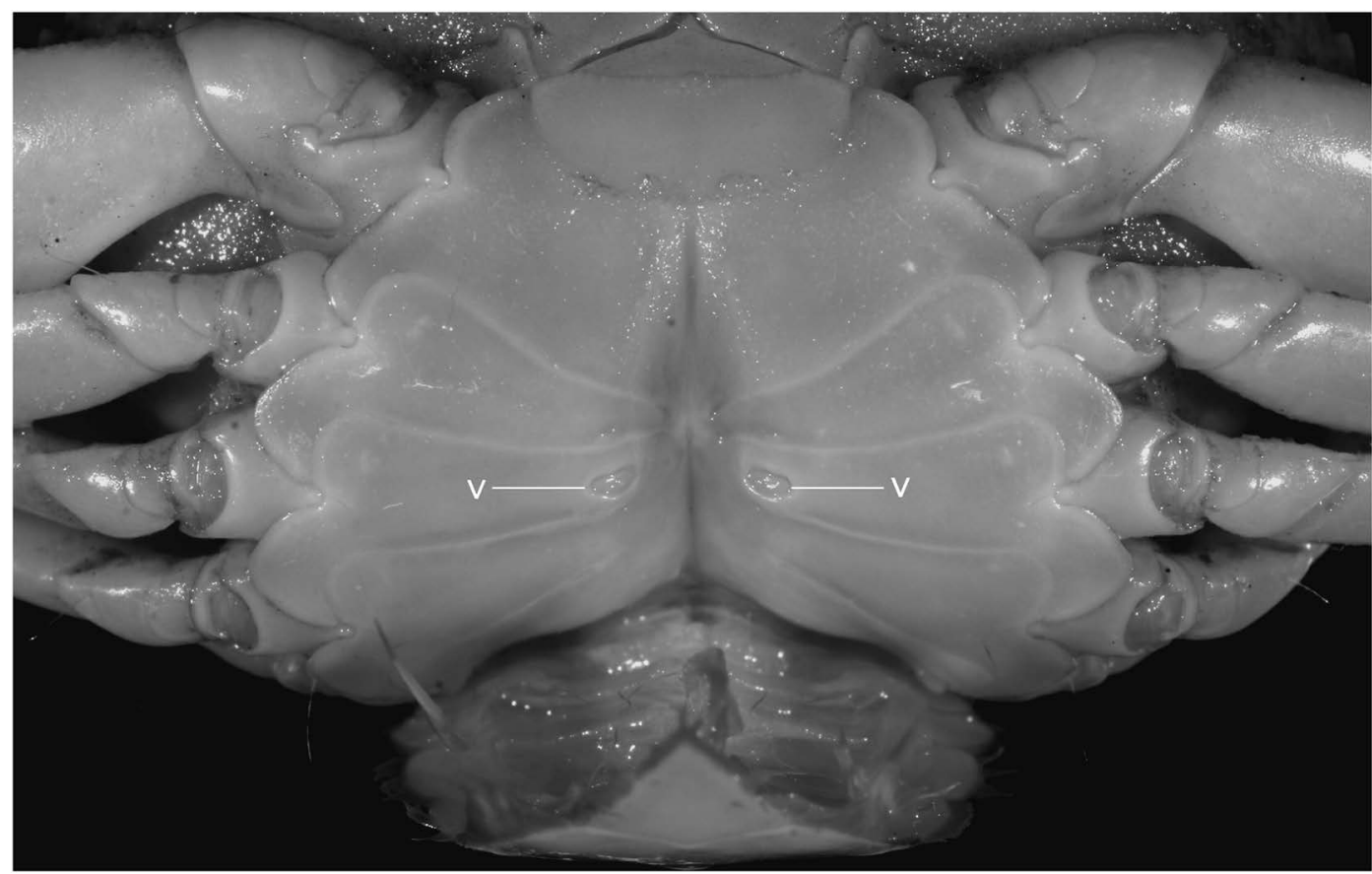

Fig. 5. Catoptrus lavicolus n. sp. Holotype, RUMF-ZC-5988, female, $13.8 \times 22.4 \mathrm{~mm}$. Sternal somites and vulvae. v, vulva.

3A); antennal flagellum long, reaching third anterolateral tooth. First maxilliped with distinct "portunoid lobe". Third maxillipeds leaving heart-shaped gap when closed (Fig. 3B); ischium with median $\mathrm{J}$-shaped groove, distal margin concave, distomesial angle produced; merus midlength about two-thirds of that of ischium, distolateral angle rounded.

Thoracic sternites 2, 3 clearly demarcated by horizontal groove; sternites 3, 4 demarcated by lateral short notches and U-shaped shallow depression; vulva horizontally oblong, longitudinally placed about middle of sternite 6 (Fig. 5).

Chelipeds almost symmetrical, slender, longer than ambulatory legs (Fig. 2); merus (Figs. $2,4)$ distinctly shorter than chela, length to width ratio 2.83 (major), 3.24 (minor) in holotype, ca. $3.05-3.10$ in a small individual (RUMF-ZC-5990, $6.2 \times 10.0 \mathrm{~mm}$ ), triangular in cross section, lower-anterior margin with 1 subproximal small tooth, 1 subdistal small tooth; palm (Fig. 4) as wide as or slightly wider than cheliped merus, glabrous surfaces smooth, with no striae or granules; fingers slender, slightly shorter than palm, tips distally clawlike and crossing when closed; immovable finger occlusal margin with ca. 4 large teeth, distal teeth sharper, with smaller teeth in between them; movable finger occlusal margin with 3 low, broad, triangular teeth, which interdigitate with 4 large teeth on immovable finger occlusal margin. Ambulatory legs (Figs. 2, 6A, B) slender, P3 longest, P5 shortest, with long, fine setae, setae denser in propodus and dactylus, ratios of lengths of P2-P5 meri to CL of holotype $0.82,0.88,0.75,0.57$, respectively; $\mathrm{P} 4$ merus length of holotype 4.92 times its width; propodus of P5 with weakly convex inner, outer margins; P5 dactylus lanceolate, dactylus narrower than respective propodus.

Pleon of large females wide, with lateral margins of somite 4-6 forming convex line, all pleonal somites free, telson longer than broad (Fig. 6C); pleopod 1-2 absent, pleopod 3-6 both endopod and exopod oblanceolate, with dense long plumose setae. Pleon of intersex 


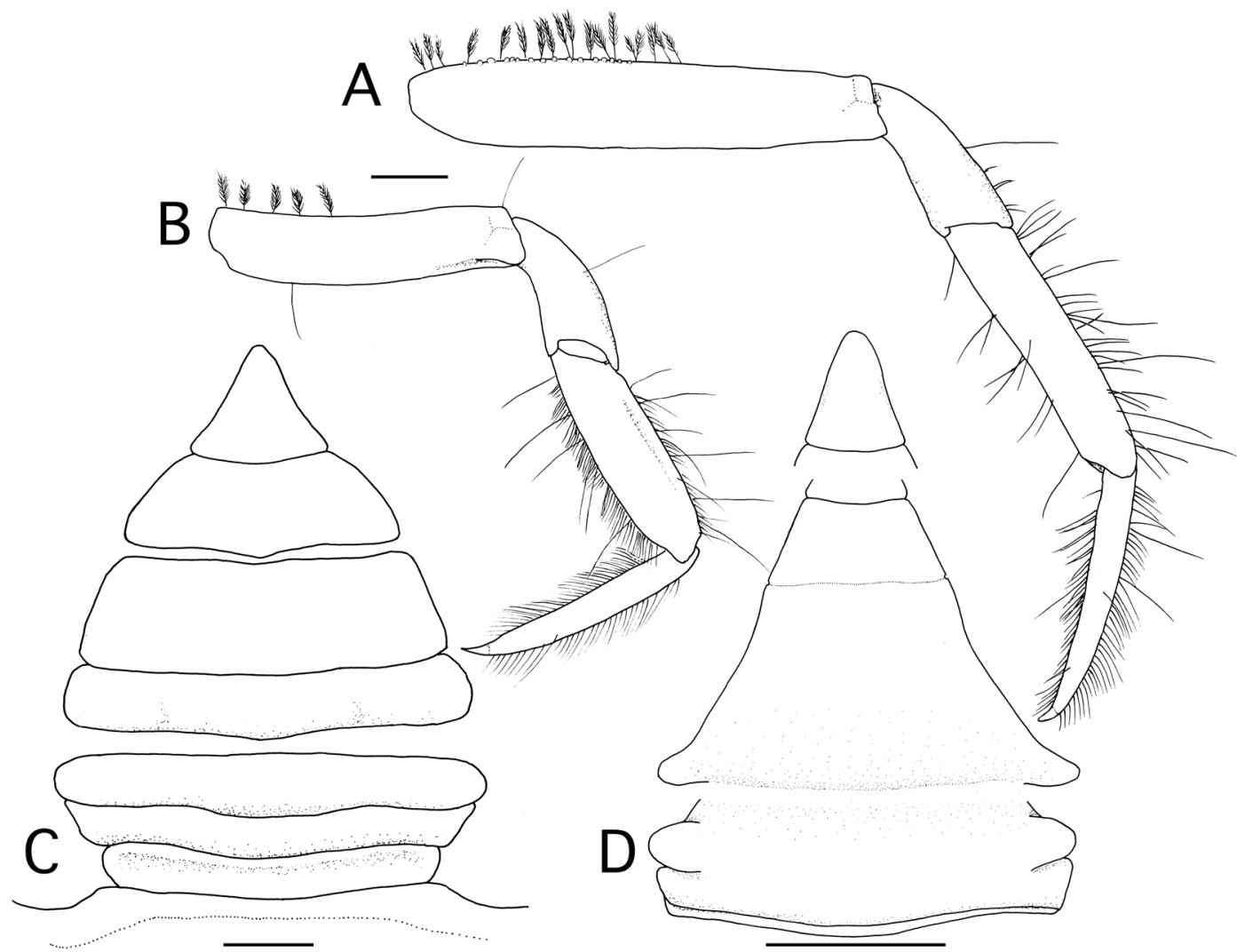

Fig. 6. Catoptrus lavicolus n. sp. A-C, holotype, RUMF-ZC-5988, female, $13.8 \times 22.4 \mathrm{~mm}$; D, paratype, RUMF-ZC-5989, intersex, $7.9 \times 12.9 \mathrm{~mm}$. A, right pereopod 3 (second ambulatory leg); B, right pereopod 5 (fourth ambulatory leg); C, D, pleon. Scale bars $=2 \mathrm{~mm}$.

individuals subtriangular, somite 2 widest, somites 2-6 fused, with superficial suture $5 / 6$, or all somites free, telson longer than broad (Fig. 6D); pleopods as in Table 1 (see also Fig. 7).

Egg small, circular, diameter $0.29-0.30 \mathrm{~mm}$ $(n=5)$.

Coloration. Entirely bright to light orange, except for black cornea, last tooth of anterolateral margin of carapace, tips of cheliped fingers and ambulatory dactyli (Figs. 1, 2).

Etymology. The name of the new species, "lavicolus" (Latin, adj., lava-dwelling), is derived from its habitat, a shallow subtidal lava rock field.
Japanese name. The standard Japanese name for this species is given here as "Youganhai-gazami", alluding to the habitat of the new species (Yougan = lava rock) and also the bright vermilion color as lava, which is sometimes observed flowing out from the crater of Sakurajima. The holotype (RUMF-ZC-5988) is designated as a standard specimen for the Japanese name of C. lavicolus $\mathbf{n} . \mathbf{s p}$.

Ecological note. Catoptrus lavicolus n. sp. was collected from deep inside large lava rocks at the shallow subtidal bed of Sakurajima, an active volcano in Kagoshima, southern Japan (Fig. 1). They were collected only when the tidal level is below the Nearly Lowest Lowwater Level (ca.-12 to $-19 \mathrm{~cm}$ ) during spring 
Table 1. Sexual features of female and intersex individuals of Catoptrus lavicolus $\mathbf{n} . \mathbf{s p}$.

\begin{tabular}{|c|c|c|c|c|c|}
\hline & $\begin{array}{c}\text { Holotype } \\
\text { RUMF-ZC-5988 } \\
\text { female } \\
13.8 \times 22.4 \mathrm{~mm} \\
\text { (Figs. } 5,6 \mathrm{C} \text { ) }\end{array}$ & $\begin{array}{l}\text { RUMF-ZC-5989 } \\
\text { intersex } \\
7.9 \times 12.9 \mathrm{~mm} \\
\text { (Figs. } 6 \mathrm{D}, 7 \mathrm{~A})\end{array}$ & $\begin{array}{l}\text { RUMF-ZC-5991 } \\
\text { intersex } \\
6.4 \times 10.2 \mathrm{~mm}\end{array}$ & $\begin{array}{l}\text { RUMF-ZC-5990 } \\
\text { intersex } \\
6.2 \times 10.0 \mathrm{~mm} \\
(\text { Fig. } 7 \mathrm{~B})\end{array}$ & $\begin{array}{l}\text { RUMF-ZC-5991 } \\
\text { intersex } \\
8.1 \times 13.6 \mathrm{~mm}\end{array}$ \\
\hline Vulva & $\bigcirc$ & O & Vestigial & - & - \\
\hline Penis & - & - & - & - & - \\
\hline Pleon & $\begin{array}{l}\text { Wide, all somites } \\
\text { free }\end{array}$ & $\begin{array}{l}\text { Narrow, somites } 2-6 \\
\text { fused (suture } 5 / 6 \\
\text { visible) }\end{array}$ & $\begin{array}{l}\text { Narrow, somites 2-6 } \\
\text { fused (suture } 5 / 6 \\
\text { visible) }\end{array}$ & $\begin{array}{l}\text { Narrow, all somites } \\
\text { free }\end{array}$ & $\begin{array}{l}\text { Narrow, somites 2-6 } \\
\text { fused (suture } 5 / 6 \\
\text { visible) }\end{array}$ \\
\hline Pl1 (G1?) & - & Right only & - & $\bigcirc$ & $\bigcirc$ \\
\hline Pl2 (G2?) & - & - & - & $\begin{array}{l}\text { Right normal size; } \\
\text { left unusually long, } \\
\text { ex present, en longer } \\
\text { than ex. }\end{array}$ & - \\
\hline P13-6 & $\begin{array}{l}\text { Both en \& ex } \\
\text { oblanceolate, with } \\
\text { dense plumose setae. }\end{array}$ & $\begin{array}{l}\text { No plumose setae. } \\
\text { All P13-6 en \& ex } \\
\text { present, except for } \\
\text { bud-like P13R ex. }\end{array}$ & $\begin{array}{l}\text { Both en \& ex } \\
\text { present, plumose } \\
\text { setae sparse. }\end{array}$ & $\begin{array}{l}\text { P13 absent; P14-6 en } \\
\& \text { ex present (except } \\
\text { for lacking P14 L [en } \\
\text { or ex?]), reduced; All } \\
\text { P14-6 with limited } \\
\text { plumose setae. }\end{array}$ & $\begin{array}{l}\text { Both en \& ex } \\
\text { present, plumose } \\
\text { setae sparse. }\end{array}$ \\
\hline
\end{tabular}

$\bigcirc$, Present in both right and left; —, absent in both right and left; en, endopod; ex, exopod; G1, first gonopod; G2, second gonopod; pl, pleopod; L, left; R, right.

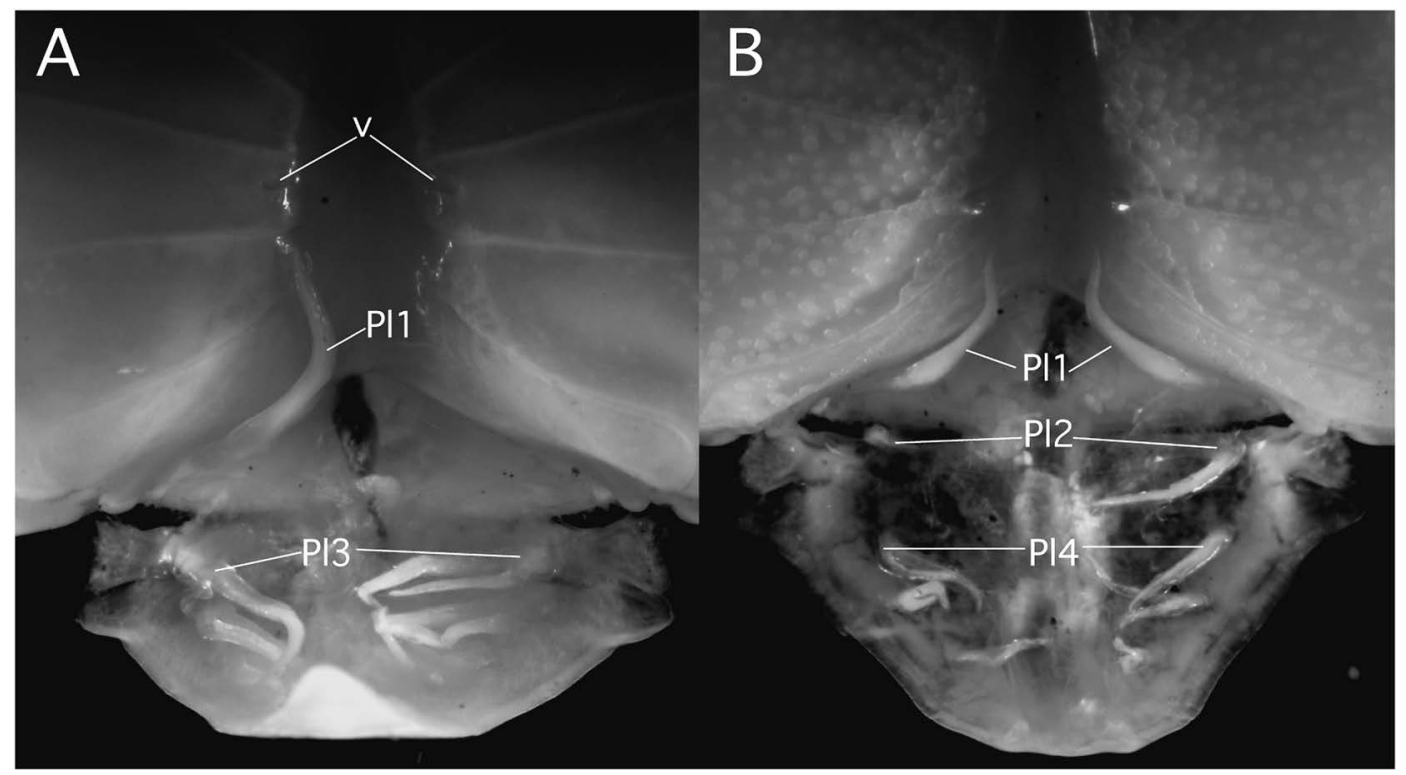

Fig. 7. Sternopleonal cavity and pleopods of intersex individuals of Catoptrus lavicolus n. sp. A, paratype, RUMF-ZC-5989, $7.9 \times$ $12.9 \mathrm{~mm}$; B, paratype, RUMF-ZC-5990, $6.2 \times 10.0 \mathrm{~mm}$. P11-4, pleopod 1-4; v, vulva. 
tide, where the water seeps out after digging lava rocks for ca. $0.5-1 \mathrm{~m}$; no individual was found during a field survey conducted in the same procedure around the lowest tide (ca. + $10 \mathrm{~cm}$ ) on another spring tide day. Catoptrus lavicolus n. sp. was not seen, even in similar environments, when potential predators, such as Chaenogobius gulosus (Gobiidae), were present. So far 16 females and 4 intersex individuals were collected, while no male was observed.

Three bait traps with fish cakes and artificial crab sticks were buried and set under lava rocks for about 25 hours (27 May 2021 13:30 28 May 2021 14:30) at the exact locations where C. lavicolus n. sp. was collected, but trapped animals were species commonly found near the surface of the rock bed (Monodonta confusa [Trochidae], Atergatis integerrimus [Xanthidae], unidentified pontoniine shrimp [Palaemonidae] and Chaenogobius gulosus
[Gobiidae]; no individual of C. lavicolus n. sp. was collected by the traps.

Remarks. Some Catoptrus species are known to have sexual dimorphism and bilateral asymmetry in chelipeds (e.g. Figs. 8, 9C, D, F). Morphologies of all Catoptrus species were described based on relatively few number of specimens, it is hence difficult to understand the extent of sexual as well as asymmetric variations in cheliped characters. Nevertheless, Catoptrus lavicolus $\mathbf{n}$. sp. can be distinguished from all described species by a combination of the characters of the carapace, ambulatory legs, and chelipeds under certain conditions.

Among the seven previously described species of Catoptrus, C. lavicolus n. sp. superficially resembles $C$. iejima Fujita \& Naruse, 2011, in their long and slender ambulatory legs. Catoptrus iejima, however, differs from the new species in its much longer ambulatory

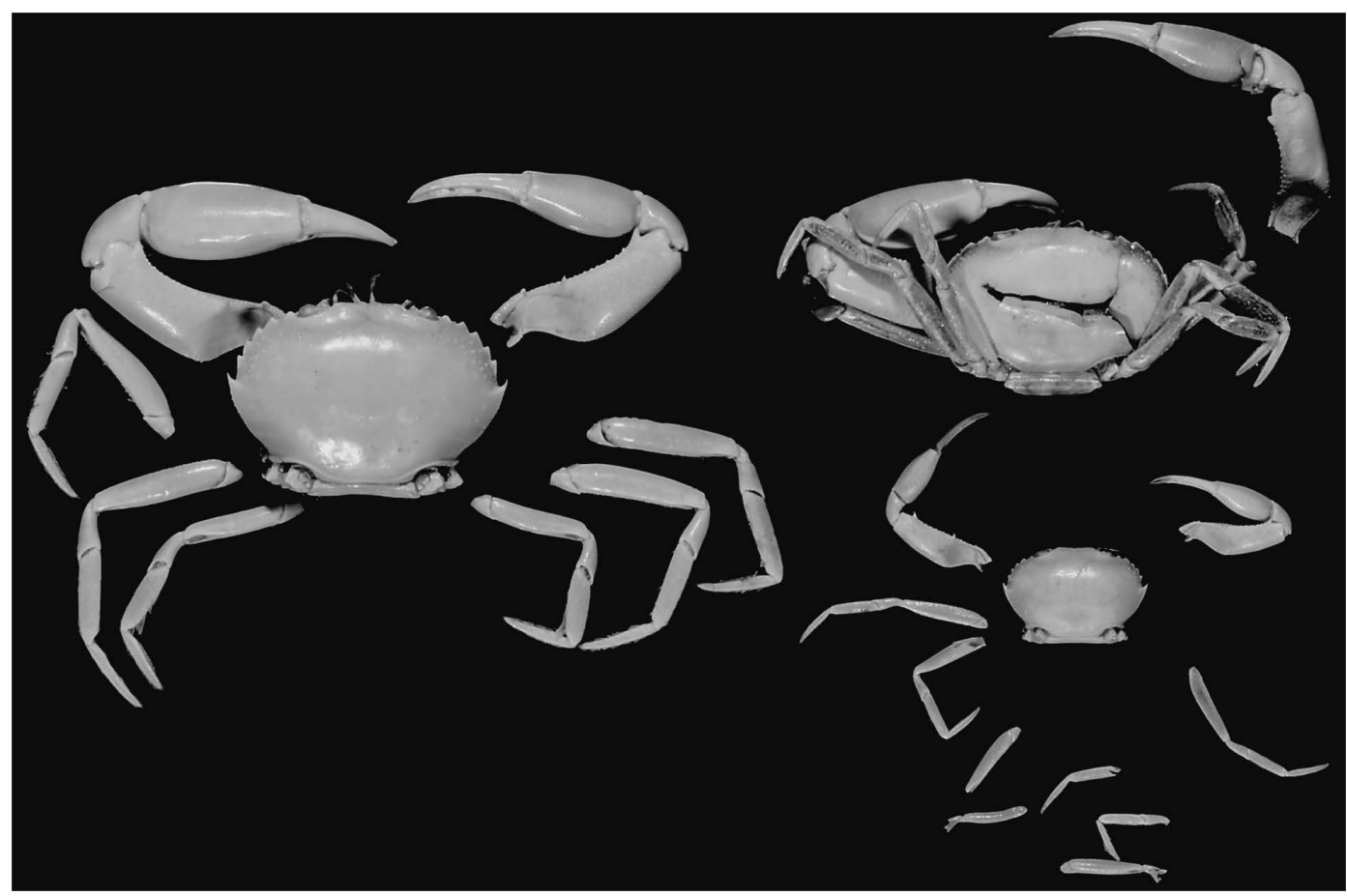

Fig. 8. Possible syntypes of Catoptrus nitidus A. Milne-Edwards, 1870 . MNHN B-22342, 2 males, $7.8 \times 12.1 \mathrm{~mm}, 6.5 \times \mathrm{ca}$. $10.1 \mathrm{~mm}$ (damaged), 1 juvenile $4.2 \times 6.4 \mathrm{~mm}$. 

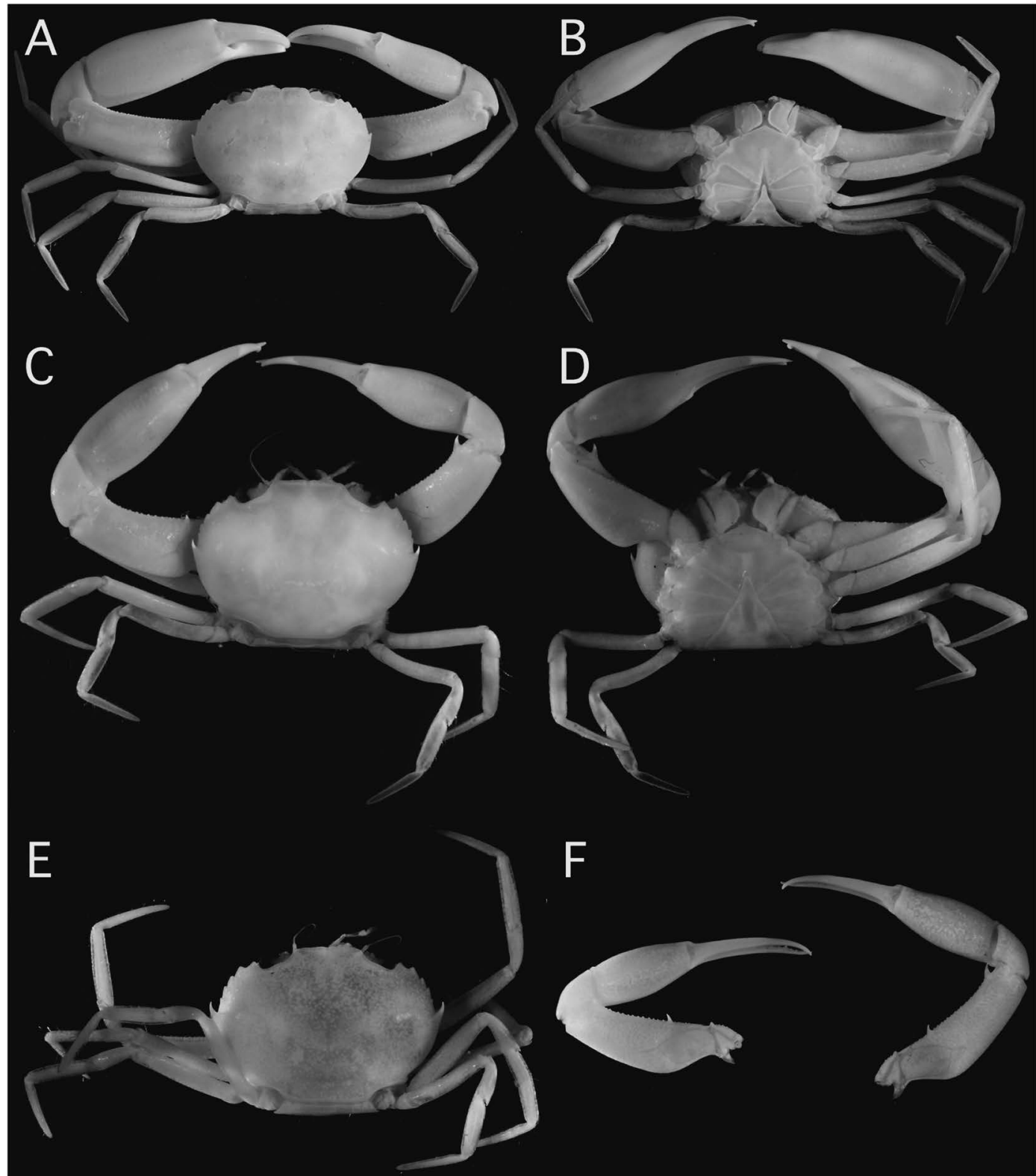

F

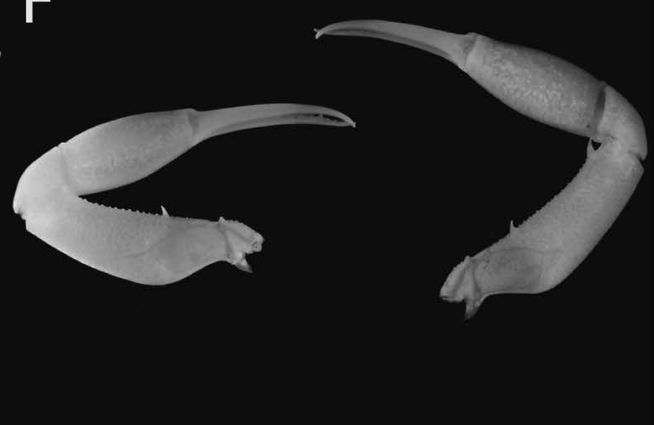

Fig. 9. Type specimens of Catoptrus species. A, B, C. inaequalis (Rathbun, 1906), syntype, USNM 29657, male, $6.9 \times 10.6$ mm; C, D, C. rathbunae Serène, 1966, holotype, MNHN B-5564, male, $5.0 \times 7.0 \mathrm{~mm}$; E, F, C. rathbunae, paratype, MNHN B-5563, female, $6.0 \times 8.5 \mathrm{~mm}$.

legs (ratios of P2-P5 meri to CL 0.98, 1.03, $0.93,0.67$ vs $0.82,0.88,0.75,0.57$ ) (Fujita \& Naruse, 2011: figs. 2, 3, 7; Fig. 2). The shape of the anterolateral teeth of the carapace is also different in the two species; the teeth of $C$. lavicolus n. sp. are proportionally larger and wider, so the bases of the teeth are adjacent to each other (Figs. 2A, B, 4A), whereas those of C. iejima are pointed and relatively small, so that their bases are well apart from each other (Fujita \& Naruse, 2011: figs. 3A, 4A, 5C).

Catoptrus lavicolus n. sp. can be distin- 
guished from $C$. nitidus A. Milne-Edwards, 1870 , by its narrower ambulatory meri (e.g. left $\mathrm{P} 4$ merus length 4.92 times width in holotype) (vs. proportionally wider in $C$. nitidus; e.g. left P4 merus length 4.29 times width in MNHN B-4639 [calculated from Fujita \& Naruse 2011: fig. 8]); external orbital tooth being triangular and only slightly exceeding or almost same level with tip of first anterolateral tooth (vs. roundly produced and distinctly exceeding with tip of first anterolateral tooth in C. nitidus), and relatively more anteromesiallydirected anterolateral teeth (vs. anteriorly directed C. nitidus) (Figs. 2, 4A, 8; Fujita \& Naruse, 2011: fig. 8).

Catoptrus marigondonensis Takeda, 2010, is notably different from all congeners in its flattened carapace, natatory P5 with widened and flattened propodus and dactylus, and the presence of more than three teeth on the lower-anterior margin of the merus of the cheliped (Takeda 2010: figs. 1, 2A-C).

The remaining four Catoptrus spp. were described based on relatively small specimens $(<\mathrm{CW} 10.6 \mathrm{~mm})$. Catoptrus inaequalis (Rathbun, 1906) and C. quinquedentatus Yang, Chen \& Tang, 2006, differ from other Catoptrus species in the absence of any tooth from the loweranterior margin of the merus of the cheliped (Fig. 9A, B; Rathbun, 1906: pl. 12, fig. 9; Yang et al. 2006: fig. 1D). It is confirmed that all examined specimens of C. lavicolus n. sp., including the smallest specimen (RUMFZC-5991, $4.7 \times 7.5 \mathrm{~mm}$ ), have these two teeth there.

Yang et al. (2006: fig. 3D) shows that C. undulatipes Yang, Chen \& Tang, 2006, has relatively stout and short cheliped merus (length to width ratio 2.44 , merus length to carapace length ratio 0.88 , calculated from Yang et al. [2006: fig. 3D, male holotype, $6.1 \times 9.4 \mathrm{~mm}$ ]). In this regard, C. lavicolus n. sp. is different, as the cheliped merus is slenderer and longer (merus length to width ratios of major/minor chelipeds 3.05/3.10, major/minor merus length to carapace length ratios $1.34 / 1.02$ in a similarsized specimen [RUMF-ZC-5990, intersex, 6.2 $\times 10.0 \mathrm{~mm}]$ ). Although available data on the cheliped merus of $C$. undulatipes and C. lavicolus n. sp. are of a male and females or intersex individuals, respectively, considering general tendency on the brachyuran sexual dimorphism on the cheliped, proportionally longer cheliped merus in intersex/female $C$. lavicolus n. sp. is a specific difference from $C$. undulatipes. Catoptrus lavicolus n. sp. also differs from $C$. undulatipes in its wider and less produced external orbital angle (vs. external orbital angle narrow and more produced in $C$. undulatipes) (Figs. 2A, B, 4A; Yang et al. 2006: fig. 3A; Yang et al. 2012: pl. 6, fig. 4).

Catoptrus rathbunae Serène, 1966, was described based on two small specimens (holotype male, $5.0 \times 7.0 \mathrm{~mm}$; paratype female, 6.0 $\times 8.5 \mathrm{~mm}$ ). Similar-sized specimens of C. lavicolus n. sp., as well as large ones, differ from C. rathbunae in the proportionally wider carapace (CW/CL 1.60-1.61 in similar-sized specimens [RUMF-ZC-5991, $4.7 \times 7.5 \mathrm{~mm}$; RUMFZC-5990, $6.2 \times 10.0 \mathrm{~mm}]$; $1.59-1.68$ times CL (mean 1.63, $\mathrm{n}=13$ ) overall) vs. 1.40-1.42), and anteromesially directed external orbital angle and first anterolateral tooth (vs. anteriorly directed in C. rathbunae) (Figs. 2, 9C-F).

\section{Acknowledgements}

We thank Kenshiro Nagayoshi and Kairi Shinomiya (Kagoshima University) for their help in field sampling. First author thanks Danièle Guinot, Danielle Defaye and Régis Cleva (MNHN) and Rafael Lemaitre and Karen Reed (USNM) for their help during the first author's stay in respective museums and access to the collections. We also thank J. C. E. Mendoza (Lee Kong Chian Natural History Museum, National University of Singapore), Milan Koch (University of Ostrava) and an anonymous reviewer, for reviewing the manuscript. This study was partially supported by "Establish- 
ment of Glocal Research and Education Network in the Amami Islands" project of Kagoshima University adopted by the Ministry of Education, Culture, Sports, Science and Technology, Japan.

\section{$\square$ Literature Cited}

Fujita, Y., \& Naruse, T., 2011. Catoptrus iejima, a new species of cavernicolous swimming crab (Crustacea: Brachyura: Portunidae) from a submarine cave at Ie Island, Ryukyu Islands, Japan. Zootaxa, 2918: 29-38.

Milne-Edwards, A., 1870. Note sur le Catoptrus nouveau genre appartenant à la division des crustacés brachyoures catométopes. Annales des Sciences naturelles, Zoologie (Paris), ser. $5,13,82$.

Ng, P. K L., Guinot, D., \& Davie, P. J. F., 2008. Systema Brachyurorum: Part I. An annotated checklist of extant brachyuran crabs of the world. Raffles Bulletin of Zoology, Supplement 17, 1-286.

Rathbun, M. J., 1906. The Brachyura and Macrura of the Hawaiian Islands. Bulletin of the United States Fish Commission, 23(3) [1903], 827-930, pls. 1-24.

Serène, R., 1966. Notes sur les genres Catoptrus et Lybistes et les Catoptrinae. Bulletin du Muséum national d'Histoire naturelle, (2)37(6), 929-1000.

Takeda, M., 2010. A new swimming crab (Crus- tacea, Decapoda, Brachyura, Portunidae) from a submarine cave in the Philippines. Bulletin of the National Museum of Nature and Science, Series A, (Zoology), 36(4), 107-113.

Yang, S.-L., Chen, H.-L., Tang B.-P., 2006. On two new species of Catoptrus A. Milne-Edwards, 1870 (Decapoda, Brachyura, Portunidae) from China. Crustaceana, 79(7), 835842.

Yang, S., Chen, H., Dai, A., 2012. Fauna Sinica, Invertebrata Vol. 49 Crustacea Decapoda Portunidae. viii +417 pp. +14 pls. Science Press, Beijing. (in Chinese with English summary)

\section{Addresses}

(TN) Tropical Biosphere Research Center, Iriomote Station, University of the Ryukyus, 870 Uehara, Taketomi, Okinawa 907-1541, Japan

(DU) Graduate School of Science and Engineering, Kagoshima University, 1-21-35 Korimoto, Kagoshima 890-0065, Japan

\section{E-mail addresses}

(TN)* naruse@lab.u-ryukyu.ac.jp) (DU)duyeno@sci.kagoshima-u.ac.jp *Corresponding author 